\title{
Pengaruh Ekuitas Merek Terhadap Keputusan Pembelian di Simetri Coffee Roaster Puri, Jakarta
}

\author{
Rachel Dyah Wiastuti ${ }^{1}$, Sarrah Kimberlee ${ }^{2}$ \\ Bina Nusantara University, rwiastuti@binus.edu \\ Bina Nusantara University, sarrahkimberlee02@gmail.com
}

\begin{abstract}
ABSTRAK
Tujuan penelitian ini adalah untuk mengetahui pengaruh ekuitas merek di SIMETRI Coffee Roasters Puri Kembangan terhadap keputusan pembelian konsumen. Penelitian menggunakan pendekatan kuantitatif. Data primer didapatkan melalui survei menggunakan kuisioner yang menggunakan pertanyaan tertutup dalam pilihan jawaban skala Likert dan dari wawancara dengan manajemen SIMETRI. Sample dalam penelitian ini adalah 100 konsumen SIMETRI Coffee Roasters, yang dihitung berdasarkan rumus Slovin, dan disebarkan berdasarkan metode convenience sampling pada Mei 2018. Ekuitas merek berperan sebagai variable bebas dan keputusan pembelian sebagai variable terikat. Deskriptif statistik digunakan untuk mengetahui bagaimana ekuitas merek dan keputusan pembelian konsumen SIMETRI. Ekuitas merek terdiri dari empat dimensi yaitu kesadaran merek, asosiasi merek, persepsi kualitas dan loyalitas merek. Sedangkan analisis korelasi dan regresi digunakan untuk mengukur hubungan dan pengaruh ekuitas merek dengan keputusan pembelian. Hasil penelitian menunjukkan bahwa ekuitas merek dan keputusan pembelian memiliki hubungan yang kuat dan positif, serta pengaruh yang signifikan.
\end{abstract}

Kata Kunci : Ekuitas Merek, Keputusan Pembelian, Kedai Kopi, Persepsi Kualitas

\begin{abstract}
The objective of this research is to determine the influence of brand equity towards consumer purchasing decision in SIMETRI Coffee Roasters Puri Kembangan. This research is using quantitative method. Primary data was colleted through interviewe and survey using questionaires with close-ended questions and Likert scale. Sampel of this research is 100 SIMETRI consumer; calculated with Slovin formula and collected with convenience sampling method. Statictic descriptive was used to determine the SIMTERI brand equity and comsumer purchase decision. Brand equity consist of brand awareneess, brand association, perceived quality, and brand loyalty. While, correlation and regression analysis were used to define the correlation and influence of brand equity towards purcahse decision. The conclusions of this research indicate that there is significant influence between brand equity towards purchasing decision, with a strong and positive correlation.
\end{abstract}

Keywords : Brand Equity, Coffee Shop, Perceived Quality, Purchase Decision

Naskah diterima : 15 Juli 2018, Naskah dipublikasikan : 15 September 2018

ISSN: 2355-6587, e-ISSN: 2528-2220

http://ejournal.bsi.ac.id/ejurnal/index.php/jp 


\section{PENDAHULUAN}

Pertumbuhan jumlah kedai kopi berjalan seiring dengan perkembangan kebiasan minum kopi diluar rumah (Maharani, 2018). Fakta bahwa Indonesia menjadi salah satu produsen biji kopi terbesar di dunia menjadi salah satu alasan tren minum kopi masih bertahan hingga saat ini (Sari, 2017). Pada wilayah Jakarta Barat sendiri, terdapat 189 gerai coffee \& tea shop yang tersebar di wilayah Tanjung Duren, Puri Indah, Kebon Jeruk, Cengkareng, Grogol, baik yang terletak di dalam shopping mall maupun yang berdiri sendiri (Qraved, 2018). SIMETRI Coffee Roasters Puri Kembangan merupakan salah satu dari 189 gerai kedai kopi dan merupakan konsep artisan pertama di wilayah Puri Indah yang dibuka pada Januari 2015.

Dengan semakin banyaknya persaingan jumlah gerai kopi di pasar, meningkat pula ketajaman persaingan di antara merek yang beroperasi (Massie, 2013). Menurut Lukman (2014), merek bukan sekedar nama atau tanda, tetapi merek merupakan sebuah upaya dari perusahaan untuk memberikan gambaran pada konsumen. Aaker menyatakan bahwa merek yang mampu memberikan nilai lebih daripada nilai yang ditawarkan produk pada pelanggannya dinyatakan sebagai merek yang memiliki ekuitas merek (Sudomo, 2013).

Soebianto (2014) mengatakan bahwa dalam dunia pemasaran sekarang ini, perusahaan yang ingin tetap bertahan dan melangkah lebih maju untuk memenangkan persaingan dinilai perlu mengetahui kondisi ekuitas merek produknya. Durianto juga menyatakan bahwa semakin kuatnya ekuitas merek suatu produk, semakin kuat pula daya tariknya di mata konsumen untuk mengkonsumsi produk tersebut yang selanjutnya dapat menggiring konsumen untuk melakukan pembelian (Massie, 2013).

Menurut Soemanagara, ekuitas merek muncul ketika persaingan produk semakin tajam menyebabkan perlunya penguatan peran merek untuk mengelompokkan produk dan jasa yang dimiliki sehingga dapat dibedakan dengan produk pesaing (Suharyani, 2015). Hanya perusahaan yang memiliki ekuitas merek yang kuat yang akan tetap mampu bersaing, merebut, dan menguasai pasar (Massie, 2013).
Pengetahuan tentang elemen - elemen ekuitas merek dan pengukurannya sangat diperlukan untuk menyusun langkah strategis dalam meningkatkan eksistensi merek yang akhirnya dapat meningkatkan jumlah pembelian konsumen (Orth et al. 2005). Ekuitas merek yang kuat akan mampu mengembangkan keberadaan suatu produk dalam persaingan apapun dan dalam jangka waktu yang panjang (Soebianto, 2014).

Kotler \& Keller (2018) melanjutkan bahwa setiap keputusan pembelian mempunyai struktur yang terdiri dari beberapa komponen, antara lain keputusan tentang jenis produk, bentuk produk, merek, tempat penjualan, jumlah produk, waktu pembelian, dan cara pembayaran. Ekuitas merek juga menjadi pertimbangan konsumen dalam melakukan keputusan pembelian (Alfionita, Suharyono, \& Yulianto, 2016). Ekuitas merek juga dibutuhkan untuk menciptakan citra yang positif melalui pelayanan dan pada dasarnya akan meningkatkan keputusan pembelian (Gunawardane, 2015).

Maka dari itu, perusahaan perlu mengidentifikasi elemen - elemen ekuitas merek yang mampu mempengaruhi kepercayaan diri pelanggan dalam keputusan pembelian yang dibuatnya (Khasanah, 2013). Begitu pula dengan SIMETRI Coffee Roasters Puri Kembangan yang merupakan pelopor kedai kopi artisan di Kawasan Puri Indah.

Tujuan penelitian ini adalah untuk (1) mengetahui ekuitas merek dimata konsumen pada SIMETRI Coffee Roasters Puri Kembangan, (2) mengetahui keputusan pembelian konsumen di SIMETRI Coffee Roasters Puri Kembangan, dan (3) mengetahui seberap besar pengaruh ekuitas merek terhadap keputusan pembelian konsumen di SIMETRI Coffee Roasters Puri Kembangan.

\section{KAJIAN LITERATUR \\ Ekuitas Merek (Brand Equity)}

Ekuitas merek merupakan seperangkat aset dan liabilitas merek yang berkaitan dengan suatu merek, nama dan simbolnya, yang menambah atau mengurangi nilai yang diberikan oleh sebuah barang atau jasa kepada perusahaan atau para pelanggan perusahaan (Aaker, 1997). Nilai ini bisa dicerminkan dalam cara konsumen berpikir, merasa, dan bertindak terhadap merek, harga, pangsa 
pasar, dan profitabilitas yang dimiliki (Kotler \& Keller, 2018). Ekuitas merek menurut Aaker (1997) dapat dikelompokkan dalam empat dimensi yaitu kesadaran merek, asosiasi merek, persepsi kualitas, dan loyalitas merek.

$H_{1}$ : Ekuitas merek yang meliputi kesadaran merek, asosiasi merek, persepsi kualitas, dan loyalitas merek secara simultan berpengaruh signifikan terhadap keputusan pembelian di SIMETRI Coffee Roasters Puri Kembangan

(1) Kesadaran Merek (Brand Awareness)

Kesadaran merek adalah tahap pertama untuk menciptakan ekuitas merek (Buil, Martinez \& Chernatony, 2013). Kesadaran merek berkaitan dengan kemampuan konsumen untuk mengenali atau mengingat kembali bahwa suatu merek merupakan bagian dari kategori produk tertentu Aaker (1997). Menurut Keller (2013) kesadaran merek terdiri atas dua dimensi; (1) Brand recognition adalah kemampuan konsumen untuk mengenali sebuah merek yang sudah diperlihatkan sebagai isyarat, (2) Brand recall adalah kemampuan konsumen untuk mencetuskan merek dalam ingatan ketika diberitahukan kategori produk, kebutuhan yang dapat dipenuhi, pembelian atau situasi penggunaan sebagai isyarat.

\section{$\mathrm{H}_{2}:$ Kesadaran merek berpengaruh signifikan terhadap keputusan pembelian di SIMETRI Coffee Roasters Puri Kembangan}

\section{(2) Asosiasi Merek (Brand Associations)}

Asosiasi merek adalah segala sesuatu yang terkait dengan memori atau ingatan terhadap sebuah merek (Tjiptono, 2008). Menurut Aaker (1997) terdapat tiga dimensi untuk mengukur asosiasi merek yaitu; (1) Attribute; yaitu penggambaran karakteristik suatu merek, apa yang konsumen pikirkan terkait dengan merek atau yang dimiliki atau melekat pada merek tersebut ketika membeli atau mengkonsumsinya (Keller, 2013). Atribut produk dibagi menjadi beberapa indikator antara lain kualitas produk, fitur produk, gaya dan desain produk, pelayanan pendukung produk, merek, kemasan, dan label (Kotler \& Armstrong, 2011). (2) Manfaat, yaitu nilai pribadi konsumen yang melekat pada atribut produk atau layanan dan dikategorikan ke dalam tiga jenis yaitu functional, experiential, dan symbolic (Keller, 2013). (3) Attitude, yaitu evaluasi kesukaan atas penggunaan produk yang berkaitan dengan motivasi diri sendiri (Aaker, 1997).

\section{$H_{3}$ : Asosiasi merek berpengaruh signifikan terhadap keputusan pembelian di SIMETRI Coffee Roasters Puri Kembangan}

\section{(3) Persepsi Kualitas (Perceived Quality)}

Persepsi kualitas adalah persepsi pelanggan terhdapa kualitas atau keunggulan suatu produk atau layanan jasa ditinjau dari fungsinya secara relative dengan produk lain (Simamora, 2003). Menurut Pappu et al. (2005), persepsi kualitas dari konsumen terkait dengan kualitas produk atau jasa yang ditawarkan. Kualitas yang ditawarkan oleh perusahaan biasanya dalam keadaan baik dan konsisten.

\section{$H_{4}$ : Persepsi kualitas berpengaruh signifikan terhadap keputusan pembelian di SIMETRI Coffee Roasters Puri Kembangan}

\section{(4) Loyalitas Merek (Brand Loyalty)}

Loyalitas merek adalah ukuran kesetiaan konsumen terhadap suatu merek dan merupakan inti dari brand equity yang menjadi gagasan sentral dalam pemasaran karena hal ini merupakan ukuran keterkaitan seorang pelanggan pada sebuah merek (Priansa, 2017). Loyalitas merek menurut Algesheimer (2005) memiliki dua dimensi; (1) Behavioural brand loyalty, didefinisikan sebagai komitmen yang dipegang teguh untuk membeli kembali atau mengulang produk atau pelayanan yang disukai secara konsisten di masa depan, meskipun terdapat pengaruh situasional dan upaya pemasaran yang menunjukkan potensi untuk menyebabkan peralihan perilaku. (2) Attitudinal brand loyalty, didefinisikan pada niat pembelian berulang, kesediaan untuk membayar harga premium atau kesediaan konsumen yang loyal 
untuk mengeluarkan uang lebih besar untuk memperoleh merek dan adanya niat untuk melakukan word of mouth yang cendurung untuk berbicara mengenai hal - hal baik tentang merek.

\section{$H_{5}:$ Loyalitas merek berpengaruh signifikan terhadap keputusan pembelian di SIMETRI Coffee Roasters Puri Kembangan}

\section{Keputusan Pembelian}

Keputusan untuk membeli yang diambil oleh pembeli sebenarnya merupakan kumpulan dari sejumlah keputusan (Dharmmesta \& Handoko, 2010). Keputusan pembelian konsumen merupakan kumpulan dari sejumlah keputusan dan terdiri dari tujuh komponen yaitu jenis produk, bentuk produk, merek, penjual, jumlah produk, waktu pembelian, dan cara pembayaran (Dharmmesta dan Handoko, 2013).

\section{(1) Jenis Produk}

Terdapat tiga indikator dalam pemilihan produk (Kotler \& Armstrong, 2011) yaitu: (a) Keunggulan produk, yang berupa tingkat kualitas yang diharapkan oleh konsumen pada produk yang dibutuhkannya dari berbagai pilihan produk. (b) Manfaat produk, yang berupa tingkat kegunaan yang dapat dirasakan oleh konsumen pada setiap pilihan produk dalam memenuhi kebutuhannya. (c) Pemilihan produk, yang berupa pilihan konsumen pada produk yang dibelinya, sesuai dengan kualitas yang diinginkan dan manfaat yang akan diperolehnya.

\section{(2) Bentuk Produk}

Konsumen dapat mengambil keputusan untuk membeli bentuk produk tertentu. Keputusan tersebut berkaitan dengan ukuran, mutu, suara, corak, dan sebagainya (Dharmmesta dan Handoko, 2010).

\section{(3) Merek}

Terdapat tiga indikator dalam memilih merek (Kotler \& Armstrong, 2011) yaitu: (a) Ketertarikan pada merek, yang berupa ketertarikan pada citra merek yang telah melekat pada produk yang dibutuhkan. (b) Kebiasaan pada merek, dimana konsumen memilih produk yang dibelinya dengan merek tertentu karena telah biasa menggunakan merek tersebut pada produk yang diputuskan untuk dibeli. (c) Kesesuaian harga, dimana konsumen selalu mempertimbangkan harga yang sesuai dengan kualitas dan manfaat produk. Jika sebuah produk memiliki citra merek yang baik, kualitas yang bagus dan manfaat yang besar, konsumen tidak akan segan mengeluarkan biaya tinggi untuk mendapatkan produk tersebut.

\section{(4) Penjual}

Adapun faktor- faktor yang mempengaruhi konsumen untuk memilih penyalur (Kotler \& Armstrong, 2011) yaitu; (a) Pelayanan yang diberikan, dimana pelayanan yang baik serta kenyamanan yang diberikan oleh distributor ataupun pengecer pada konsumen membuat konsumen akan selalu memilih lokasi tersebut untuk membeli produk yang dibutuhkannya. (b) Kemudahan untuk mendapatkan, dimana lokasi pendistribusian (pengecer, grosir, dan lain - lain) mudah dijangkau dalam waktu singkat dan menyediakan barang yang dibutuhkan. (c) Persediaan barang, dimana kebutuhan dan keinginan konsumen terhadap suatu produk tidak dapat dipastikan terjadinya, tetapi persediaan barang yang memadai pada penyalur akan membuat konsumen memilih untuk melakukan pembelian di tempat tersebut

\section{(5) Jumlah Produk}

Terdapat dua indikator dalam jumlah produk (Kotler \& Armstrong, 2011) yaitu; (a) Keputusan jumlah pembelian, dimana selain keputusan pada suatu pilihan merek yang diambil konsumen, konsumen juga dapat menentukan jumlah produk yang akan dibelinya sesuai kebutuhan. (b) Keputusan pembelian untuk persediaan, dimana konsumen membeli produk selain untuk memenuhi kebutuhannya, juga melakukan beberapa tindakan persiapan dengan sejumlah persediaan produk yang mungkin dibutuhkan pada saat mendatang.

\section{(6) Waktu Pembelian}

Terdapat tiga perbedaan pemilihan waktu pembelian (Kotler \& Armstrong, 2011) yaitu; (a) Kesesuaian dengan kebutuhan, dimana ketika seseorang merasa membutuhkan sesuatu dan merasa perlu melakukan pembelian, ia akan melakukan pembelian. (b) Keuntungan yang dirasakan, dimana ketika konsumen memenuhi kebutuhannya terhadap suatu produk pada saat tertentu, saat itu konsumen akan merasakan keuntungan sesuai kebutuhannya melalui produk yang dibeli 
sesuai waktu dibutuhkannya. (c) Alasan pembelian, dimana setiap produk selalu memiliki alasan untuk memenuhi kebutuhan konsumen pada saat dibutuhkan.

\section{(7) Cara Pembayaran}

Konsumen harus mengambil keputusan tentang metode atau cara pembayaran produk yang dibeli, apakah secara tunai atau cicilan. Keputusan tersebut akan memengaruhi keputusan tentang penjualan dan jumlah pembeliannya. Perusahaan harus mengetahui keinginan pembeli terhadap cara pembayaran (Dharmmesta dan Handoko, 2010)

\section{METODE PENELITIAN}

Penelitian ini menggunakan pendekatan kuantitatif, yaitu untuk meneliti pada sampel tertentu, dengan pengumpulan data menggunakan instrumen penelitian, dan analisis data bersifat statistik, dengan tujuan untuk menguji hipotesis (Sugiyono, 2016). Penelitian ini bersifat, cross-sectional yaitu dilakukan pada satu saat tertentu saja (Rangkuti, 2016). Gambar 1 menunjukkan desain penelitian ini yang menggunakan dua variabel, yaitu ekuitas merek sebagai variabel independen dan keputusan pembelian sebagai variabel dependen.

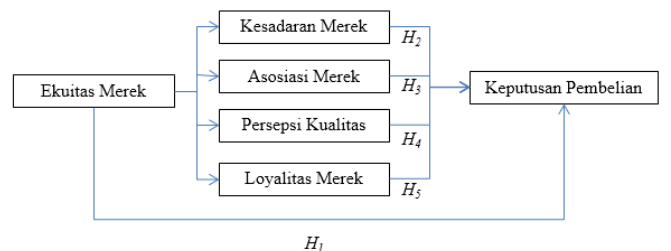

Gambar 1

Desain Penelitian

Sumber: Penulis (2018)

\section{Teknik Pengumpulan Data}

Data primer didapatkan melalui hasil olah kuisioner dan wawancara. Kuisioner disebarkan secara langsung kepada responden pada 24-31 Mei 2018. Kuisioner menggunakan skala likert (5 untuk sangat setuju, 4 untuk setuju, 3 untuk cukup setuju, 2 untuk tidak setuju, dan 1 untuk sangat tidak setuju) dan terbagi menjadi 3 bagian. Bagian pertama adalah profil responden yang terdiri dari tujuh pertanyaan; jenis kelamin, usia, pekerjaan, domisili, sumber mengetahui, sumber informasi, frekuensi kunjungan satu tahun terakhir. Bagian kedua adalah 30 pernyataan mengenai ekuitas merek dan 16 pernyataan mengenai keputusan pembelian.

Wawancara dilakukan sebanyak dua kali kepada Bapak Andrey Raharja selaku CEO dan Co-owner SIMETRI Coffee Roasters pada 8 April 2018 dan 16 Mei 2018 dengan tujuan untuk mengetahui sejarah perkembangan SIMETRI Coffee Roasters Puri Kembangan, ekuitas merek menurut pihak manajemen, dan masalah yang terjadi. Terdapat 17 butir pertanyaan terbuka yang diajukan.

\section{Populasi, Sampel dan Pilot Study}

Populasi dalam penelitian ini adalah konsumen SIMETRI Coffee Roasters Puri Kembangan, yaitu mereka yang pernah mengkonsumsi produk SIMETRI Coffee Roasters Puri Kembangan periode Januari 2017 sampai Januari 2018, dengan total sebanyak 23,226 orang. Jumlah sample diperoleh melalui perhitungan rumus Slovin sehingga didapat hasil 99,57 yang kemudian dibulatkan menjadi 100 responden. Teknik pengambilan sampel yaitu nonpropability sampling dan convenience sampling, dimana peneliti tidak memberi peluang atau kesempatan sama bagi setiap unsur atau anggota populasi untuk dipilih menjadi sampel (Sugiyono, 2016).

Untuk mengetahui apakah setiap indikator kuisioner valid dan reliable maka diperlukan dilakukan pilot study (Vogel \& Draper-Rodi, 2017). Pilot study dilakukan kepada 30 responden pada 24-26 Mei 2018. Hasil olah data menujukkan bahwa 46 butir pernyataan kuisioner memiliki $r_{\text {hitung }}$ yang lebih besar dari $r_{\text {tabel }}$ (0.312), sehingga dapat dinyatakan bahwa semua butir pernyataan kuisioner adalah valid. Sedangkan nilai koefisien reliabilitas $\left(\mathrm{r}_{11}\right)>0.6$ untuk semua butir pernyataan juga sehingga dapat dinyatakan reliable (Siregar, 2015)

\section{Teknik Analisis Data}

Statistik deskriptif digunakan untuk menjawab pertanyaan penelitian pertama dan kedua dengan melihat nilai mean dan standar deviasi (Sugiyono, 2016). Analisis korelasi digunakan untuk mengetahui kekuatan dan arah hubungan antara dua variabel (Gunawan, 2016) yaitu antara ekuitas merek dan keputusan pembelian. Analisis regresi digunakan untuk mengukur pengaruh antar variabel bebas dan variabel terikat (Siregar, 
2015), yaitu antar ekuitas merek dan keputusan pembelian. Uji $\mathrm{F}$ dan $\mathrm{Uji} t$ dilakukan sebagai cara pengujian hipotesis (Ghozali, 2016). Sebagai alat bantu statistik, peneliti menggunakan SPSS version 25.

\section{PEMBAHASAN}

\section{SIMETRI Coffee Roasters Puri}

\section{Kembangan}

SIMETRI Coffee Roasters (SCR) Puri

Kembangan didirikan pada bulan Januari 2015 di bawah PT. Deux Essential. Nama "SIMETRI" tercetus karena holder share utama PT. Deux Essential yaitu Bapak Billy Kurniawan dan Ibu Yeni F. Liu ingin menyelaraskan antara coffee shop, coffee roastery, dan menu brunch yang disediakan. Pada tahun 2018, SIMETRI Coffee Roasters telah memiliki tiga cabang di antaranya Puri Kembangan (Jakarta Barat), Jogjakarta, dan Mega Kuningan (Jakarta Selatan).

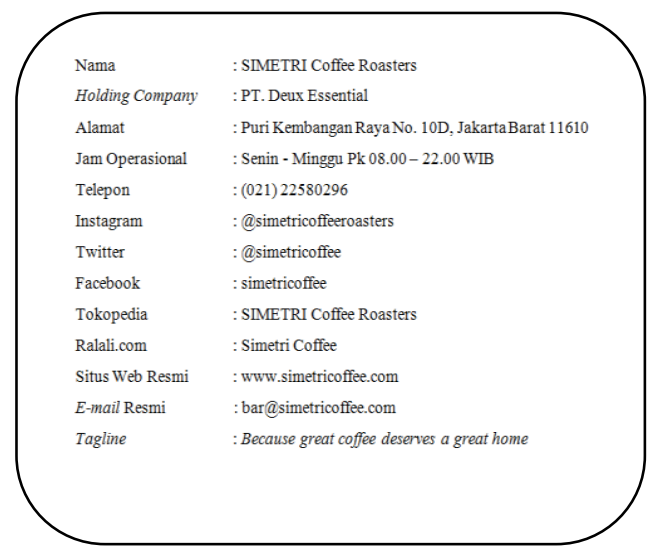

Gambar 2

Profil Objek Penelitian

Sumber: SCR Puri (2018)
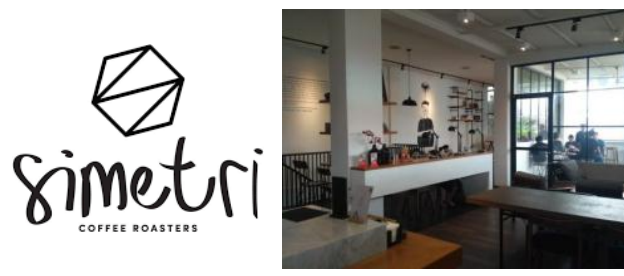

Gambar 3

Logo dan Area Indoor Objek

Sumber: SCR (2018)

Gambar 2 menujukkan profil SCR yang dijadikan objek penelitian ini dan Gambar 3 menunjukkan logo SCR serta area indoor dalam SCR Puri Kembangan.

\section{Profil Responden}

Berdasarkan Tabel 1, mayoritas profil responden dalam penelitian ini adalah pria (58\%), berusia 23-30 tahun (52\%), bekerja sebagai karyawan (44\%), dan berdomisili di Jakarta (84\%). Faktor yang menyebabkan mayoritas konsumen adalah pria karena jenis produk yang dijual SCR adalah kopi dengan manual brew yang biasanya memang lebih disukai kaum pria. Selain itu, hal ini didukung dengan ketersedianya area merokok yang cukup luas dan nyaman untuk konsumen, sehingga semakin menambah minat para konsumen pria untuk dating dan nongkrong di SCR.

Tabel 1

Profil Responden

\begin{tabular}{cccc}
\hline \multirow{2}{*}{$\begin{array}{c}\text { Profil } \\
\text { Responden }\end{array}$} & $\begin{array}{c}\text { Jawaban } \\
\text { Pilihan } \\
\text { Responden }\end{array}$ & n & $\%$ \\
\hline Jenis & Laki - Laki & 58 & $58 \%$ \\
\cline { 2 - 4 } Kelamin & Perempuan & 42 & $42 \%$ \\
\hline \multirow{4}{*}{ Usia } & $\leq 22$ tahun & 25 & $25 \%$ \\
\cline { 2 - 4 } & $23-30$ tahun & 52 & $52 \%$ \\
\cline { 2 - 4 } & $31-40$ tahun & 17 & $17 \%$ \\
\cline { 2 - 4 } & $\geq 40$ tahun & 6 & $6 \%$ \\
\hline \multirow{3}{*}{ Pekerjaan } & Karyawan & 44 & $44 \%$ \\
\cline { 2 - 4 } & Wirausaha & 32 & $32 \%$ \\
\cline { 2 - 4 } & Pelajar & 22 & $22 \%$ \\
\cline { 2 - 4 } & Lainnya & 2 & $2 \%$ \\
\cline { 2 - 4 } Jakarta & 84 & $84 \%$ \\
\cline { 2 - 4 } Domisili & Bekasi & 2 & $2 \%$ \\
\cline { 2 - 4 } Saat Ini & Tangerang & 10 & $10 \%$ \\
\cline { 2 - 4 } & Bogor & 1 & 1 \\
\cline { 2 - 4 } & Lainnya & 3 & $3 \%$ \\
\hline
\end{tabular}

Sumber: Hasil Olah Data (2018)

Gambar 4 menjelaskan bahwa mayoritas konsumen mengetahui adanya SCR dari teman $(50 \%)$. Hal ini menunjukkan bahwa rekomendasi teman sangat berpengaruh terhadap minat orang lain untuk menjadi konsumen SCR. Pada urutan kedua, konsumen mengetahui SCR dengan cara melihat langsung (29\%). Hal ini menunjukkan bahwa signboard yang terletak di area parkir sudah terlihat oleh orang yang melewati area Puri Kembangan. Mengetahui dari event memiliki nilai paling sedikit sebesar $2 \%$ 
karena SCR jarang mengadakan acara seperti workshop dan pameran.

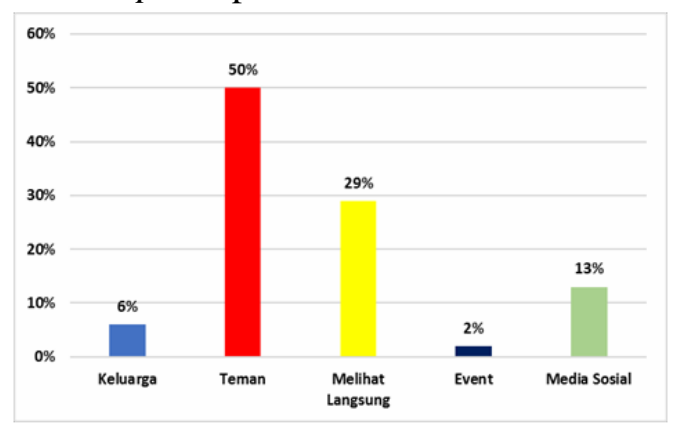

Gambar 4

Sumber Mengetahui SCR

Sumber: Hasil Olah Data (2018)

Gambar 5 menjelaskan bahwa mayoritas konsumen mendapatkan informasi lebih dalam mengenai SCR dari media sosial $(72 \%)$ dan FB Platform (24\%). Hal ini selaras dengan perkembangan kemajuan teknologi dan kemdaan akses internet. Data ini juga menjadi petunjuk bagi manajemen SCR untuk memastikan semua informasi yang tercantum di social media dan semua $F B$ platform adalah informasi yang terbaru dan memastikan juga agar selalu merespon permintaan pengunjung maya.

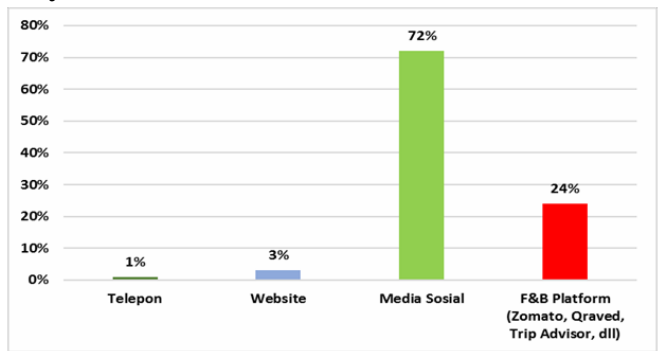

Gambar 5

Sumber Mendapatkan Informasi SCR Sumber: Hasil Olah Data (2018)

Gambar 6 menjelaskan bahwa mayoritas konsumen pernah melakukan pembelian produk SCR paling sedikit sebanyak 6 kali dalam satu tahun terakhir (34\%). Jika dilihat, mayoritas responden adalah mereka yang pernah berkunjung sebelumnya sebanyak $68 \%$ dan pengunjung pertama kali sebanyak $32 \%$.

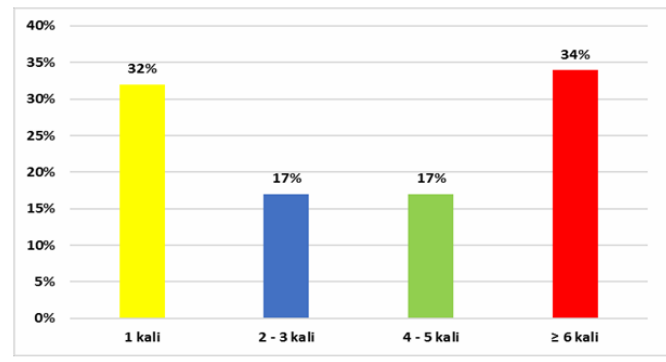

Gambar 6

Frekuensi Kunjungan

Sumber: Hasil Olah Data (2018)

\section{Analisis Desriptif Ekuitas Merek}

Tabel 2 menunjukkan deskriptif statistik ekuitas merek, dimana nilai standar deviasi berkisar pada nilai terendah sebesar 0.595 yang artinya titik data cenderung sangat dekat dengan mean dan nilai tertinggi sebesar 1.012 yang artinya data tersebar di sejumlah nilai. Ekuitas merek memiliki nilai mean sebesar 3.801 yang artinya konsumen netral cenderung setuju terhadap ekuitas merek SIMETRI Coffee Roasters Puri Kembangan.

Tabel 2

Deskriptif Statistik Ekuitas Merek

\begin{tabular}{|c|c|c|c|}
\hline Dimensi & Pertanyaan & $\begin{array}{l}\text { Std. } \\
\text { Dev }\end{array}$ & Mean \\
\hline \multirow{4}{*}{$\begin{array}{l}\text { Kesadaran } \\
\text { Merek } \\
(3.618)\end{array}$} & $\begin{array}{l}\text { Dapat mengenali merek bila } \\
\text { diberi bantuan }\end{array}$ & 0.950 & 3.63 \\
\hline & $\begin{array}{l}\text { Salah satu merek yang muncul di } \\
\text { benak konsumen }\end{array}$ & 0.975 & 3.59 \\
\hline & $\begin{array}{l}\text { Dapat membedakan merek di } \\
\text { saat terdapat pilihan lain }\end{array}$ & 0.892 & 3.55 \\
\hline & $\begin{array}{l}\text { Dapat mengingat merek bila } \\
\text { diberi bantuan }\end{array}$ & 0.969 & 3.70 \\
\hline \multirow{15}{*}{$\begin{array}{l}\text { Asosiasi } \\
\text { Merek } \\
(3.831)\end{array}$} & Adanya kualitas produk & 0.595 & 4.10 \\
\hline & $\begin{array}{l}\text { Produk yang ditawarkan dapat } \\
\text { disesuaikan dengan selera }\end{array}$ & 0.745 & 4.01 \\
\hline & $\begin{array}{l}\text { Adanya desain untuk area indoor } \\
\& \\
\text { outdoor (smoking) }\end{array}$ & 0.637 & 4.28 \\
\hline & $\begin{array}{l}\text { Adanya layanan pesan antar } \\
\text { online }\end{array}$ & 0.856 & 3.71 \\
\hline & Pemilihan merek itu sendiri & 0.842 & 3.59 \\
\hline & Kemasan/packaging dari produk & 0.748 & 3.81 \\
\hline & $\begin{array}{l}\text { Adanya label pada setiap jenis } \\
\text { biji kopi }\end{array}$ & 0.867 & 3.66 \\
\hline & $\begin{array}{l}\text { Adanya informasi harga pada } \\
\text { menu }\end{array}$ & 0.729 & 4.12 \\
\hline & Karyawan yang bekerja & 0.893 & 4.10 \\
\hline & Ulasan (review) dari orang lain & 0.883 & 3.78 \\
\hline & $\begin{array}{l}\text { Mendapatkan manfaat dasar dari } \\
\text { produk }\end{array}$ & 0.860 & 3.74 \\
\hline & $\begin{array}{l}\text { Mendapatkan manfaat untuk } \\
\text { mencari kesenangan }\end{array}$ & 0.718 & 3.90 \\
\hline & $\begin{array}{l}\text { Mendapatkan status sosial terkait } \\
\text { dengan produk }\end{array}$ & 0.909 & 3.11 \\
\hline & Ulasan setelah konsumsi produk & 0.811 & 3.78 \\
\hline & Motivasi dari diri saya sendiri & 0.874 & 3.77 \\
\hline
\end{tabular}




\begin{tabular}{|c|c|c|c|}
\hline \multirow{4}{*}{$\begin{array}{l}\text { Persepsi } \\
\text { Kualitas } \\
(4.130)\end{array}$} & Produk berkualitas baik & 0.493 & 4.17 \\
\hline & Kualitas produk konsisten & 0.662 & 3.92 \\
\hline & Produk dapat dipercaya & 0.581 & 4.16 \\
\hline & $\begin{array}{l}\text { Mendapatkan hasil memuaskan } \\
\text { ketika produk sesuai dengan } \\
\text { selera }\end{array}$ & 0.649 & 4.27 \\
\hline \multirow{7}{*}{$\begin{array}{l}\text { Loyalitas } \\
\text { Merek } \\
(3.626)\end{array}$} & $\begin{array}{l}\text { Berkomitmen untuk membeli } \\
\text { produk kembali secara konsisten }\end{array}$ & 0.875 & 3.61 \\
\hline & $\begin{array}{l}\text { Tetap membeli produk meski } \\
\text { terdapat pengaruh lain }\end{array}$ & 1.006 & 3.33 \\
\hline & $\begin{array}{l}\text { Tetap membeli produk meski ada } \\
\text { upaya pemasaran lain }\end{array}$ & 1.026 & 3.24 \\
\hline & $\begin{array}{l}\text { Berniat melakukan pembelian } \\
\text { ulang produk }\end{array}$ & 0.666 & 3.98 \\
\hline & $\begin{array}{l}\text { Bersedia membayar lebih untuk } \\
\text { mendapatkan produk }\end{array}$ & 1.012 & 3.19 \\
\hline & $\begin{array}{l}\text { Berminat untuk } \\
\text { merekomendasikan merek } \\
\text { kepada orang lain }\end{array}$ & 0.659 & 4.10 \\
\hline & $\begin{array}{l}\text { Cenderung membicarakan hal } \\
\text { baik tentang merek }\end{array}$ & 0.728 & 3.93 \\
\hline \multicolumn{4}{|c|}{ Mean Ekuitas Merek (3.801) } \\
\hline
\end{tabular}

Dimensi pertama ekuitas merek yaitu kesadaran merek memperoleh mean 3.618 yang artinya konsumen netral ke arah setuju terkait kesadaran merek SCR. Dimensi ini memiliki nilai mean paling rendah apabila dibandingkan dengan dimensi lainnya. Konsumen menyatakan netral ke arah setuju bila SCR adalah merek yang muncul di benaknya. Konsumen juga belum mampu untuk membedakan produk SCR dengan produk lain. Namun, konsumen ternyata netral cenderung setuju untuk dapat mengingat SCR diberi bantuan.

Dimensi kedua ekuitas merek yaitu asosiasi merek memperoleh mean 3.831 yang artinya konsumen netral ke arah setuju terkait asosiasi merek SCR. Dimensi ini menunjukkan pernyataan mengenai alasan kesan konsumen muncul terhadap SCR. Konsumen setuju cenderung sangat setuju bahwa kesan muncul karena kualitas produk. Konsumen ternyata setuju cenderung sangat setuju bahwa kesan muncul karena produk yang ditawarkan dapat disesuaikan dengan selera konsumen. Konsumen juga menyatakan setuju cenderung sangat setuju terhadap kesan yang muncul karena adanya desain pada area indoor dan area merokok. Area indoor yang nyaman serta area merokok yang cukup luas mendukung kesan konsumen terhadap SCR. Sedangkan konsumen netral cenderung setuju bahwa kesan muncul karena adanya layanan pesan antar online (GoFood). Konsumen netral cenderung setuju bahwa kesan muncul karena pemilihan merek SCR itu sendiri. Konsumen netral cenderung setuju bahwa kesan muncul karena kemasan atau packaging dari produk. Konsumen netral ke arah setuju bahwa kesan muncul karena alasan adanya label pada setiap jenis biji kopi yang ditawarkan. Konsumen setuju cenderung sangat setuju bahwa kesan muncul karena adanya informasi harga pada menu dari setiap produk yang ditawarkan. Konsumen setuju cenderung sangat setuju bahwa kesan muncul karena karyawan yang bekerja di SCR. Konsumen netral ke arah setuju bahwa kesan muncul karena adanya ulasan (review) dari orang lain. Konsumen netral ke arah setuju bahwa kesan muncul karena mendapat manfaat dasar dari produk yaitu haus ataupun lapar. Konsumen netral cenderung setuju bahwa kesan muncul karena mendapatkan manfaat untuk mencari kesenangan. Konsumen netral cenderung setuju bahwa kesan muncul karena mendapatkan status sosial terkait dengan produk. Konsumen netral ke arah setuju bahwa kesan muncul karena ulasan pribadi setelah mengkonsumsi produk. Konsumen netral ke arah setuju bahwa kesan muncul karena adanya motivasi dari dalam diri konsumen sendiri.

Dimensi ketiga ekuitas merek yaitu persepsi kualitas memperoleh mean 4.13 yang artinya konsumen setuju cenderung sangat setuju terkait persepsi kualitas SCR. Dimensi ini memiliki nilai mean paling tinggi bila dibandingkan dengan dimensi yang lain. Konsumen setuju cenderung sangat setuju bahwa produk SCR berkualitas baik. Konsumen netral ke arah setuju bila kualitas produk SCR konsisten. Konsumen setuju cenderung sangat setuju bila produk SCR dapat dipercaya. Konsumen setuju cenderung sangat setuju bila mendapatkan hasil yang memuaskan ketika produk yang dipesan sesuai dengan selera.

Dimensi keempat ekuitas merek yaitu loyalitas merek memperoleh mean 3.626 yang artinya konsumen netral cenderung setuju terkait loyalitas merek SCR. Konsumen netral cenderung setuju bila berkomitmen untuk membeli kembali produk SCR secara konsisten. Konsumen netral cenderung setuju untuk membeli produk meski terdapat pengaruh lain, misalnya diajak oleh kerabat ke 
kedai kopi lain. Konsumen netral cenderung setuju untuk tetap membeli produk SCR bila ada upaya pemasaran lain seperti promo potongan harga di kedai kopi lain. Konsumen netral cenderung setuju untuk berniat melakukan pembelian ulang produk SCR. Konsumen netral cenderung setuju bersedia membayar lebih untuk mendapatkan produk SCR. Konsumen setuju cenderung sangat setuju untuk merekomendasikan SIMETRI Coffee Roasters Puri Kembangan kepada orang lain, misalnya keluarga, teman, rekan kerja, dan kerabat lainnya. Konsumen netral cenderung setuju untuk membicarakan hal baik tentang SIMETRI Coffee Roasters kepada orang lain.

Analisis Desriptif Keputusan Pembelian

Tabel 3 menunjukkan deskriptif statistik ekuitas merek, dimana nilai terendah sebesar 0.644 yang artinya titik data cenderung sangat dekat dengan mean dan nilai tertinggi sebesar 1.072 artinya data tersebar di sejumlah nilai. Keputusan pembelian memiliki nilai mean sebesar 3.771 yang artinya konsumen setuju cenderung netral terkait keputusan pembelian produk SIMETRI Coffee Roasters Puri Kembangan.

Tabel 3

Deskriptif Statistik Keputusan Pembelian

\begin{tabular}{|c|c|c|c|}
\hline Dimensi & Pertanyaan & $\begin{array}{l}\text { Std. } \\
\text { Dev }\end{array}$ & Mean \\
\hline \multirow{2}{*}{$\begin{array}{c}\text { Jenis Produk } \\
(3.785)\end{array}$} & Keunggulan produk & 0.737 & 3.89 \\
\hline & Manfaat produk & 0.803 & 3.68 \\
\hline \multicolumn{2}{|c|}{ Bentuk ProdukUkuran Produk } & 0.881 & 3.54 \\
\hline$(3.850)$ & Kualitas Produk & 0.703 & 4.03 \\
\hline \multirow[t]{3}{*}{$\begin{array}{l}\text { Merek } \\
(3.667)\end{array}$} & $\begin{array}{l}\text { Tertarik pada citra } \\
\text { merek yang melekat } \\
\text { pada produk }\end{array}$ & 0.960 & 3.37 \\
\hline & $\begin{array}{l}\text { Telah terbiasa } \\
\text { menggunakan merek }\end{array}$ & 0.967 & 3.71 \\
\hline & $\begin{array}{l}\text { Harga sesuai dengan } \\
\text { kualitas dan manfaat } \\
\text { produk }\end{array}$ & 0.787 & 3.92 \\
\hline \multirow{3}{*}{$\begin{array}{l}\text { Penjual } \\
(4.337)\end{array}$} & Pelayanan yang baik & 0.644 & 4.36 \\
\hline & $\begin{array}{l}\text { Kenyamanan yang } \\
\text { diberikan }\end{array}$ & 0.709 & 4.32 \\
\hline & Lokasi mudah dijangkau & 0.682 & 4,33 \\
\hline \multirow[t]{3}{*}{$\begin{array}{c}\text { Jumlah Produk } \\
(3.723)\end{array}$} & $\begin{array}{l}\text { Produk yang dibutuhkan } \\
\text { tersedia }\end{array}$ & 0.745 & 4.03 \\
\hline & $\begin{array}{l}\text { Jumlah produk yang } \\
\text { dapat ditentukan sesuai } \\
\text { kebutuhan }\end{array}$ & 0.827 & 3.77 \\
\hline & $\begin{array}{l}\text { Membutuhkan sejumlah } \\
\text { produk untuk persediaan } \\
\text { di masa mendatang }\end{array}$ & 0.991 & 3.37 \\
\hline $\begin{array}{c}\text { Waktu } \\
\text { Pembelian }\end{array}$ & $\begin{array}{l}\text { Benar - benar } \\
\text { membutuhkan produk }\end{array}$ & 0.920 & 3.11 \\
\hline
\end{tabular}

\begin{tabular}{|c|c|c|c|}
\hline \multirow[t]{2}{*}{$(3.420)$} & \multicolumn{3}{|l|}{ yang ditawarkan } \\
\hline & $\begin{array}{l}\text { Keuntungan yang } \\
\text { didapat sesuai dengan } \\
\text { kebutuhan }\end{array}$ & 0.763 & 3.73 \\
\hline $\begin{array}{c}\text { Cara } \\
\text { Pembayaran } \\
(3.680)\end{array}$ & $\begin{array}{l}\text { Pilihan metode } \\
\text { pembayaran yang } \\
\text { tersedia }\end{array}$ & 1.072 & 3.68 \\
\hline \multicolumn{4}{|c|}{ Mean Keputusan Pembelian (3.771) } \\
\hline
\end{tabular}

Dimensi pertama keputusan pembelian yaitu jenis produk memperoleh mean 3.785 yang artinya konsumen netral ke arah setuju bahwa jenis produk berkaitan dengan keputusan pembelian di SCR. Konsumen netral ke arah setuju untuk membeli karena keunggulan produk. Konsumen netral cenderung setuju untuk membeli karena manfaat produk. Dalam dimensi jenis produk, konsumen lebih banyak memutuskan untuk membeli karena produk SCR unggul dan bukan karena mendapatan manfaat setelah mengkonsumsi.

Dimensi kedua keputusan pembelian yaitu bentuk produk memperoleh mean 3.785 yang artinya konsumen netral ke arah setuju bahwa bentuk produk berkaitan dengan keputusan pembelian di SCR. Konsumen lebih banyak memutuskan untuk membeli produk SCR karena ukuran dan bukan karena kualitas produknya yang baik.

Dimensi ketiga keputusan pembelian yaitu merek memperoleh mean 3.667 yang artinya konsumen netral cenderung setuju bahwa merek berkaitan dengan keputusan pembelian di SCR. Hal ini menunjukkan konsumen netral ke arah setuju untuk membeli karena tertarik pada citra merek. Hal ini menunjukkan bahwa konsumen netral cenderung setuju untuk membeli karena telah terbiasa mengkonsumsi. Konsumen netral cenderung setuju untuk membeli karena harga yang ditawarkan SCR sesuai dengan kualitas dan manfaat produk yang ditawarkan sehingga menguntungkan konsumen. Indikator bagian ketiga ini memiliki nilai mean paling tinggi daripada indikator bagian pertama ataupun kedua. Artinya, konsumen lebih banyak memutuskan untuk membeli karena harga sudah sesuai dengan kualitas dan manfaat yang didapat oleh konsumen, bukan karena citra merek atau sudah terbiasa mengkonsumsi.

Dimensi keempat keputusan pembelian yaitu penjual memperoleh mean 4.337 yang artinya 
konsumen setuju ke arah sangat setuju bahwa penjual berkaitan dengan keputusan pembelian di SCR. Dimensi ini memiliki nilai mean paling tinggi bila dibandingkan dengan dimensi lain. Indikator penjual ini memiliki mean paling besar yang artinya konsumen setuju cenderung sangat setuju untuk membeli karena pelayanan yang baik. Konsumen setuju cenderung sangat setuju untuk membeli karena SCR memberikan kenyamanan. Konsumen setuju cenderung sangat setuju untuk membeli karena lokasi SCR mudah dijangkau.

Dimensi kelima keputusan pembelian yaitu jumlah produk memperoleh mean 3.723 yang artinya konsumen netral cenderung setuju bahwa jumlah produk berkaitan dengan keputusan pembelian di SCR. Konsumen setuju cenderung sangat setuju untuk membeli karena produk yang konsumen butuhkan disediakan. Konsumen netral cenderung setuju untuk membeli karena jumlah produk yang disediakan oleh SCR dapat ditentukan sesuai kebutuhan konsumen, misalnya konsumen memesan 5 gelas Ice Creamy Latte (salah satu nama produk minuman SCR) dan SCR mampu memenuhinya. Konsumen netral cenderung setuju untuk membeli produk dengan alasan sebagai persediaan di masa mendatang.

Dimensi keenam keputusan pembelian yaitu waktu pembelian memperoleh mean 3.507 yang artinya konsumen netral cenderung setuju bahwa waktu pembelian berkaitan dengan keputusan pembelian di SCR. Konsumen netral cenderung setuju untuk membeli dengan alasan benar - benar membutuhkan produk SCR. Konsumen netral cenderung setuju untuk membeli dengan alasan keuntungan saat mengkonsumsi SCR sesuai dengan kebutuhan. Konsumen lebih banyak merasakan keuntungan yang didapatkan dan telah sesuai dengan kebutuhan meskipun sesungguhnya tidak benar - benar membutuhkan produk SCR.

Dimensi ketujuh keputusan pembelian yaitu cara pembayaran memperoleh mean 3.680 . Hal ini menunjukkan bahwa konsumen netral cenderung setuju untuk membeli dengan alasan pilihan metode pembayaran di SCR. Sampai saat ini, SCR hanya melayani pembayaran berupa tunai dan debit BCA dan belum bisa berupa kartu kredit maupun kartu instant lainnya seperti Flazz BCA, e-Money Mandiri, Brizi BRI.

\section{Uji Korelasi}

Tabel 4 menunjukkan hasil analisis korelasi ekuitas merek dan keputusan pembelian. Nilai koefisien korelasi sebesar 0.753 menunjukkan bahwa ekuitas merek memiliki hubungan yang kuat dengan keputusan pembelian. Koefisien korelasi ini tergolong kuat karena memiliki nilai 0.60 - 0.799 (Siregar, 2015). Hal ini sejalan dengan penelitian yang dilakukan oleh Khoiriyah (2015) dimana kedua variabel ini memiliki hubungan yang kuat.

Tabel 4

Uji Korelasi

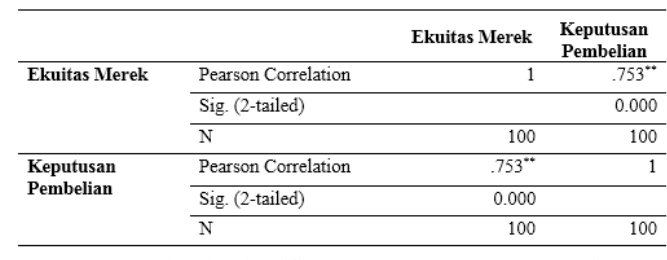

**. Correlation is significant at the 0.01 level (2-tailed).

Sumber: Hasil Olah Data (2018)

Tabel 5

Coefficients Regresi

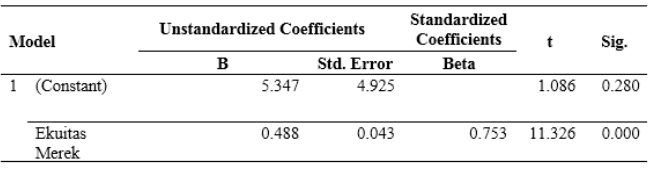

Sumber: Hasil Olah Data (2018)

\section{Uji Regresi}

Tabel 5 menunjukkan nilai konstanta (a) sebesar 5.347 sedangkan nilai ekuitas merek (b atau koefisien regresi) sebesar 0.488. Maka persamaan regresi adalah:

$$
\mathrm{Y}=5.347+0.488 \mathrm{X}
$$

Persamaan regresi menjelaskan bahwa konstanta sebesar 5.347 memiliki arti bahwa nilai konsisten variabel keputusan pembelian adalah sebesar 5.347. Koefisien regresi $X$ sebesar 0.488 menyatakan bahwa setiap penambahan 1 nilai ekuitas merek, maka nilai keputusan pembelian bertambah sebesar 0.488 . Koefisien regresi ini bernilai positif sehingga menunjukkan bahwa pengaruh variabel ekuitas merek terhadap variabel keputusan pembelian adalah positif atau searah. Hal ini berarti jika terjadi penambahan nilai pada ekuitas merek, maka akan menambah nilai keputusan pembelian, dan 
juga sebaliknya; jika terjadi penurunan nilai pada ekuitas merek, maka akan menurunkan nilai keputusan pembelian.

Tabel 6 menunjukkan bahwa koefisien determinasi atau yang biasa disebut dengan $\mathrm{R}$ square memperoleh nilai sebesar 0.567 . Hal ini menunjukkan bahwa ekuitas merek memberikan sumbangan sebesar $56,7 \%$ kepada keputusan pembelian. Atau dalam kata lain sebesar $56.7 \%$ keputusan pembelian dapat dijelaskan oleh ekuitas merek. Namun, sebesar 43,3\% dari keputusan pembelian ditentukan oleh variabel lain yang tidak diteliti dalam penelitian ini.

Tabel 6

\begin{tabular}{|c|c|c|c|c|}
\hline \multicolumn{5}{|c|}{ Model Summary } \\
\hline Model & $\mathbf{R}$ & R Square & $\begin{array}{l}\text { Adjusted R } \\
\text { Square }\end{array}$ & $\begin{array}{l}\text { Std. Error of } \\
\text { the Estimate }\end{array}$ \\
\hline 1 & $.753^{\mathrm{a}}$ & 0.567 & 0.562 & 5.018 \\
\hline
\end{tabular}

\section{Uji t}

Tabel 5 dapat diketahui bahwa $t_{\text {hitung }}(11,326)$ lebih besar dari $t_{\text {tabel }}(1,985)$, sehingga dapat dinyatakan bahwa ekuitas merek memiliki pengaruh terhadap keputusan pembelian. Kemudian berdasarkan nilai signifikansi sebesar $0.000<0.05$, sehingga dapat dinyatakan bahwa ekuitas merek berpengaruh signifikan terhadap keputusan pembelian.

\section{Pengujian Hipotesis}

Tabel 7 menunjukkan apakah ekuitas merek yang meliputi kesadaran merek, asosiasi merek, persepsi kualitas, dan loyalitas merek secara simultan berpengaruh signifikan atau tidak terhadap keputusan pembelian.

Tabel 7

Uji F Hipoptesis $\mathrm{H}_{1}$

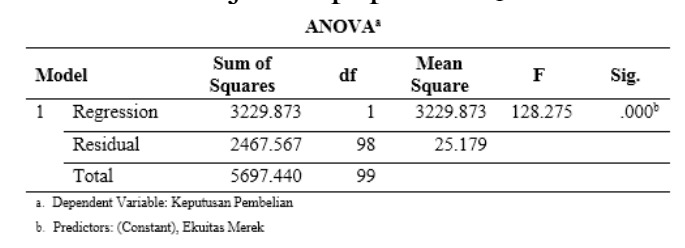

Sumber: Hasil Olah Data (2018)

Dapat diketahui bahwa $\mathrm{F}_{\text {hitung }}(128.275)>\mathrm{F}_{\text {tabel }}$ (3.94), sehingga dapat dinyatakan bahwa ekuitas merek yang meliputi kesadaran merek, asosiasi merek, persepsi kualitas, dan loyalitas merek secara simultan berpengaruh terhadap keputusan pembelian. Pada kolom Sig., signifikansi memperoleh nilai sebesar $0.000<$ 0.05 , sehingga dapat dinyatakan bahwa ekuitas merek meliputi kesadaran merek, asosiasi merek, persepsi kualitas, dan loyalitas merek secara simultan berpengaruh signifikan terhadap keputusan pembelian. Dengan demikian, Hipotesis $\mathrm{H}_{1}$ diterima yaitu ekuitas merek yang meliputi kesadaran merek, asosiasi merek, persepsi kualitas, dan loyalitas merek secara simultan berpengaruh terhadap keputusan pembelian di SIMETRI Coffee Roasters Puri Kembangan. Hal ini menunjukkan bahwa ekuitas merek pada SCR dapat menjadi salah satu faktor yang signifikan dalam berkontribusi terhadap keputusan pembelian konsumen.

Tabel 8

Uji Parsial Hipotesis $\mathrm{H}_{2}$

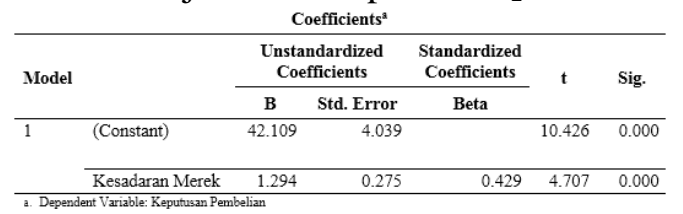

Sumber: Hasil Olah Data (2018)

Tabel 8 menunjukkan hasil uji parsial Hipotesis $\mathrm{H}_{2}$. Pada kolom t, diketahui bahwa $t_{\text {hitung }}(4.707)>t_{\text {tabel }}$ (1.985), sehingga dapat dinyatakan bahwa kesadaran merek memiliki pengaruh terhadap keputusan pembelian. Pada kolom Sig., signifikansi memperoleh nilai sebesar $0.000<0.05$, sehingga dapat dinyatakan bahwa kesadaran merek berpengaruh signifikan terhadap keputusan pembelian. Dengan demikian, Hipotesis $\mathrm{H}_{2}$ diterima yaitu kesadaran merek berpengaruh signifikan terhadap keputusan pembelian di SIMETRI Coffee Roasters Puri Kembangan. Hal ini menunjukkan bahwa kesadaran merek pada SCR dapat menjadi salah satu faktor yang signifikan dalam berkontribusi terhadap keputusan pembelian konsumen.

Tabel 9 menunjukkan hasil uji parsial Hipotesis $\mathrm{H}_{3}$. Pada kolom t, diketahui bahwa $t_{\text {hitung }}(9.572)>t_{\text {tabel }}(1.985)$, sehingga dapat dinyatakan bahwa asosiasi merek memiliki pengaruh terhadap keputusan pembelian. Pada kolom Sig., signifikansi memperoleh nilai sebesar $0.000<0.05$, sehingga dapat dinyatakan bahwa asosiasi merek berpengaruh signifikan terhadap keputusan pembelian. Dengan demikian, Hipotesis $\mathrm{H}_{3}$ diterima yaitu asosiasi merek berpengaruh signifikan 
terhadap keputusan pembelian di SIMETRI Coffee Roasters Puri Kembangan. Hal ini menunjukkan bahwa asosiasi merek pada SCR dapat menjadi salah satu faktor yang signifikan dalam berkontribusi terhadap keputusan pembelian konsumen.

Tabel 9

Uji Parsial Hipotesis $\mathrm{H}_{3}$

\begin{tabular}{|c|c|c|c|c|c|c|}
\hline & & & Coefficie & & & \\
\hline \multirow{2}{*}{\multicolumn{2}{|c|}{ Model }} & \multicolumn{2}{|c|}{$\begin{array}{l}\text { Unstandardized } \\
\text { Coefficients }\end{array}$} & \multirow{2}{*}{$\begin{array}{c}\begin{array}{c}\text { Standardized } \\
\text { Coefficients }\end{array} \\
\text { Beta }\end{array}$} & \multirow{2}{*}{$t$} & \multirow{2}{*}{ Sig. } \\
\hline & & B & Std. Error & & & \\
\hline \multirow[t]{2}{*}{1} & (Constant) & 14.739 & 4.847 & & 3.041 & 0.003 \\
\hline & $\begin{array}{l}\text { Asosiasi } \\
\text { Merek }\end{array}$ & 0.802 & 0.084 & 0.695 & 9.572 & 0.000 \\
\hline
\end{tabular}

Sumber: Hasil Olah Data (2018)

Tabel 10

Uji Parsial Hipotesis $\mathrm{H}_{4}$

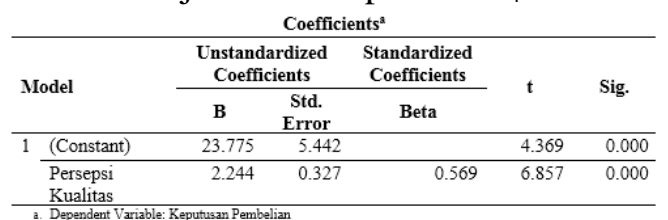

Sumber: Hasil Olah Data (2018)

Tabel 10 menunjukkan hasil uji parsial Hipotesis $\mathrm{H}_{4}$. Pada kolom t, diketahui bahwa $t_{\text {hitung }}(6.857)>t_{\text {tabel }}$ (1.985), sehingga dapat dinyatakan bahwa persepsi kualitas memiliki pengaruh terhadap keputusan pembelian. Pada kolom Sig., signifikansi memperoleh nilai sebesar $0.000<0.05$, sehingga dapat dinyatakan bahwa persepsi kualitas berpengaruh signifikan terhadap keputusan pembelian. Dengan demikian, Hipotesis $\mathrm{H}_{4}$ diterima yaitu persepsi kualitas berpengaruh signifikan terhadap keputusan pembelian di SIMETRI Coffee Roasters Puri Kembangan. Hal ini menunjukkan bahwa persepsi kualitas pada SCR dapat menjadi salah satu faktor yang signifikan dalam berkontribusi terhadap keputusan pembelian konsumen.

Tabel 11

Uji Parsial Hipotesis $\mathrm{H}_{5}$

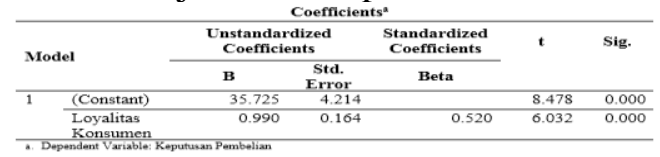

Sumber: Hasil Olah Data (2018)

Tabel 11 menunjukkan hasil uji parsial Hipotesis $\mathrm{H}_{5}$. Pada kolom $\mathrm{t}$, diketahui bahwa $t_{\text {hitung }}(6.032)>t_{\text {tabel }}$ (1.985), sehingga dapat dinyatakan bahwa loyalitas konsumen memiliki pengaruh terhadap keputusan pembelian. Pada kolom Sig., signifikansi memperoleh nilai sebesar $0.000<0.05$, sehingga dapat dinyatakan bahwa loyalitas merek berpengaruh signifikan terhadap keputusan pembelian Dengan demikian, Hipotesis $\mathrm{H}_{5}$ diterima yaitu loyalitas merek berpengaruh signifikan terhadap Keputusan pembelian di SIMETRI Coffee Roasters Puri Kembangan. Hal ini menunjukkan bahwa loyalitas konsumen pada SCR dapat menjadi salah satu faktor yang signifikan dalam berkontribusi terhadap keputusan pembelian konsumen.

\section{PENUTUP}

Ekuitas merek SIMETRI Coffee Roasters Puri Kembangan dinyatakan netral cenderung setuju menurut konsumen yang diukur berdasarkan empat dimensi yaitu kesadaran merek, asosiasi merek, persepsi kualitas, dan loyalitas merek. Keputusan Pembelian konsumen SIMETRI Coffee Roasters Puri Kembangan dinyatakan netral cenderung setuju yang diukur berdasarkan tujuh dimensi yaitu jumlah produk, bentuk produk, merek, penjual, jumlah produk, waktu pembelian, dan cara pembayaran. Ekuitas merek SIMETRI Coffee Roasters Puri Kembangan, baik secara parsial maupun secara simultan berpengaruh signifikan terhadap keputusan pembelian konsumen, dimana keduanya memiliki hubungan yang kuat dan searah.

\section{Saran Praktis}

Saran kepada pihak SCR; (1) Memastikan informasi terkait produk yang ada di media sosial dan F\&B Platform (Zomato, Qraved, Trip Advisor) untuk selalu terbaru. Informasi yang dimaksud bisa berupa tersedianya guest beans, misalnya dari Coffee Smith atau Cupping Room yang dijual dalam kurun waktu tertentu. (2) Membuat program promosi sebagai salah satu strategi pemasaran, khusus untuk karyawan dan wirausaha yang menjadi mayoritas konsumen. Program promosi yang dimaksud seperti happy hour untuk coffee dan main course pada pukul 18.30-20.30. (3) Meningkatkan kesadaran merek dengan melakukan co-branding bersama brand besar secara berkala yang memiliki profil konsumen sama dengan SIMETRI Coffee Roasters. Contoh co-branding seperti membuat 
kolaborasi atau kerjasama secara berkala dengan Manual Jakarta atau Indonesia Coffee Exchange. (4) Memastikan bahwa produk yang ditawarkan selalu dapat disesuaikan dengan selera atau permintaan konsumen, misalnya pada produk minuman, konsumen bisa meminta kadar gula dan es yang lebih sedikit dari standar normal. (6) Menambah pilihan cara pembayaran, yaitu menggunakan kartu debit selain BCA dan kartu kredit.

\section{Saran Akademis}

Saran untuk penelitian selanjutnya dengan menambah variabel bebas lainnya seperti brand image dan brand positioning, serta meneliti faktor yang belum diteliti, seperti gaya hidup.

\section{REFERENSI}

Aaker, David. (1997). Manajemen Ekuitas Merek. Jakarta: Spektrum

Alfionita, C. M., Suharyono, \& Yulianto, E. (2016). Pengaruh Ekuitas Merek Terhadap Keputusan Pembelian (Survei Pada Pembeli Oppo Smartphone di Counter Handphone MATOS). Jurnal Administrasi Bisnis, 36, 178- 185.

Algesheimer, R., Dholakia, U.M. \& Herrmann, A. (2005). The Social Influence of Brand Community; Evidence from European Car Clubs. Journal of Marketing, 69, 19-34.

Buil, I., Martinez, E., \& Chernatony, L. d. (2013). The Influence of Brand Equity on Consumer Responses. Journal of Consumer Marketing, 62-74.

Dharmmesta, B. S., \& Handoko, T. H. (2010). Manajemen Pemasaran: Analisa Perilaku Konsumen. Yogyakarta: BPFEYogyakarta

Dharmmesta, B. S., \& Handoko, T. H. (2013). Manajemen Pemasaran Analisis Perilaku Konsumen. Yogyakkarta: BPFEYogyakarta.

Ghozali, I. (2016). Aplikasi Analisis Multivariete Dengan Program IBM SPSS 23. Semarang: Badan Penerbit Universitas Diponegoro.
Gunawan, I. (2016). Pengantar Statistika Inferensial. Depok: PT Rajagrafindo Persada.

Gunawardane, N. R. (2015). Impact of Brand Equity towards Purchasing Decision: A Situation on Mobile Telecommunication Services of Sri Lanka. Journal of Marketing Management, 4(1), 100 - 117

Keller, K. L. (2013). Strategic Brand Management. Harlow: Pearson Education Limited.

Khasanah, I. (2013). Analisis Pengaruh Ekuitas Merek terhadap Keputusan Pembelian Mie Instan Sedaap di Semarang. Jurnal Dinamika Manajemen, 4(1), 93-102.

Khoiriyah. (2015). Pengaruh Ekuitas Merek terhadap Keputusan Pembelian Produk Rumah Tangga Merek Tupperware di Pekanbaru. Jurnal Online Mahasiswa Fakultas Ekonomi Universitas Riau, 2(1), 1-14.

Kotler, P., \& Armstrong, G. (2011). Marketing an Introduction. New Jersey: Pearson Prentice Hall

Kotler, P., \& Keller, K. L. (2018). Manajemen Pemasaran. Jakarta: PT Indeks.

Lukman, M. D. (2014). Analisis Pengaruh Ekuitas Merek Terhadap Keputusan Pembelian dan Kepuasan Konsumen Produk Teh Botol Sosro KEmasan Kotak. Jurnal Administrasi Bisnis, 10, 64-81.

Maharani, S. (2018, Mei 8). Fenomena 'Demam' Coffee Shop di Indonesia. Retrieved from https://kumparan.com

Massie, P. V. (2013). Ekuitas Merek Pengaruhnya Terhadap Keputusan Pembelian XL Mobile Data Service di Kota Manado. Jurnal EMBA, 1, 14741481.

Priansa, D. J. (2017). Komunikasi Pemasaran Terpadu Pada Era Media Sosial. Bandung: CV Pustaka Setia. 
Orth, U., Wolf, M \& Dodd, T. H. (2005). Dimensions of Wine Region Equity and Theirs Impact on Cunsumers preference. Journal of Product and Brand Management. 14(2), 88-97.

Pappu, R., Quester, P.G. and Cooksey, R.W. (2005). Consumer-based brand equity: improving the measurement. Empirical evidence. Journal of Product and Brand Management. Vol. 14(3),143-54

Qraved. (2018). Coffee \& Tea Shop in Jakarta Barat. Diambil kembali dari www.qraved.com.

Rangkuti, F. (2016). Riset Pemasaran. Jakarta: PT Gramedia Pustaka Utama.

Sari, I. K. (2017, November 11). Tren Minum Kopi di Kalangan Milenial Tetap Eksis 10 Tahun ke Depan. Diambil kembalidari https://kumparan.com

Simamora, B. (2003). Memenangkan Pasar dengan Pemasaran Efektif dan Proftable. Jakarta: Gramedia

Siregar, S. (2015). Statistik Parametrik untuk Penelitian Kuantitatif Dilengkapi dengan Perhitungan Manual dan Aplikasi SPSS versi 17. Jakarta: PT Bumi Aksara.

Soebianto, A. (2014). Analisis Pengaruh Faktor - Faktor Brand Equity Sepeda Motor Merek Honda Terhadap Keputusan Pembelian Pada Konsumen di Kota Bandung. E-Journal Graduate Unpar, 1, 14-37.

Sudomo, S. (2013). Pengaruh Ekuitas Merek Terhadap Keputusan Pembelian (Studi Kasus Konsumen Pepsodent di Kabupaten Bantul). JBMA, 1, 33-48.

Sugiyono. (2016). Metode Penelitian Kuantitatif, Kualitatif, dan $R \& D$. Bandung: Alfabeta.

Suharyani, K. (2015). Pengaruh Ekuitas Merek Terhadap Keputusan Pembelian Produk Minuman Teh Botol Sosro Pada Mahasiswa Jurusan Pendidikan Ekonomi Undiksha 2015. Jurnal Jurusan Pendidikan Ekonomi (JJPE), 5, 1- 13.
Tjiptono, F. (2008). Strategi Pemasaran. Yogyakarta: Penerbit Andi

Vogel, S., \& Draper-Rodi, J. (2017). The importance of pilot studies, how to write them and what they mean. International Journal of Osteopathic Medicine, 23, 2-3.

\section{BIODATA PENULIS}

Rachel Dyah Wiastuti, SST.Par., MM., M.Par adalah Faculty Member di Universitas Bina Nusantara pada Hotel Management Department dan menyelesaikan pendidikan DIV Hotel Administration di STP Bandung, S2 Pariwisata di STP Trisakti dan S2 Pemasaran di Universitas Sahid.

Sarrah Kimberlee, SST adalah alumni DIV Hotel Management Universitas Bina Nusantara dan saat ini bekerja sebagai Barista di Simetri Coffee Roaster Puri KembanganJakarta. 